\title{
Conservation significance of intact forest landscapes in the Scandinavian Mountains Green Belt
}

\author{
Johan Svensson • Jakub W. Bubnicki • Bengt Gunnar Jonsson • \\ Jon Andersson • Grzegorz Mikusiński (i)
}

Received: 6 July 2019/Accepted: 1 August 2020/Published online: 10 August 2020

(C) The Author(s) 2020

\begin{abstract}
Context As forest harvesting remains high, there is a crucial need to assess the remaining large, contiguous and intact forests, regionally, nationally and globally. Objectives Our objective was to analyze the spatial patterns and structural connectivity of intact and primary forests in northern Sweden with focus on the Scandinavian Mountain region; one of the few remaining large European intact forest landscapes.
\end{abstract}

Electronic supplementary material The online version of this article (https://doi.org/10.1007/s10980-020-01088-4) contains supplementary material, which is available to authorized users.

J. Svensson · B. G. Jonsson

Department of Wildlife, Fish and Environmental Studies, Swedish University of Agricultural Sciences, SLU, 90183 Umeå, Sweden

e-mail: johan.svensson@slu.se

J. W. Bubnicki

Mammal Research Institute, Polish Academy of Sciences, 17-230 Białowieża, Poland

B. G. Jonsson

Department of Natural Sciences, Mid Sweden University, 85170 Sundsvall, Sweden

J. Andersson

Sweco Environment AB, Umestan Företagspark Hus 12, Box 110, 90103 Umeå, Sweden
Methods Over 22 million ha with 14.5 million ha boreal and subalpine forest and with data consisting of a 60-70 year retrospective sequence, we analyzed distribution, density and connectivity of forests that have not been clear cut, using moving window and landscape analyzes derived from Circuitscape.

Results We revealed a contiguous, connected and semi-connected intact forest landscape forming a distinct Green Belt south to north along the mountain range. Almost $60 \%$ of the forestland remains intact, including contiguous clusters 10,000 ha and larger. The connectivity is particularly high in protected areas with primary forests outside contributing substantially to overall connectivity. We found gaps in connectivity




in the southern parts, and furthermore low or absent connectivity across the whole inland and coastal areas of northern Sweden.

Conclusions Given its ecological values, the Scandinavian Mountains Green Belt is a key entity supporting ecological legacies, boreal biodiversity and ecosystem services, resilience and adaptive capacity, which needs to be safeguarded for the future. On the very large areas outside the mountain region, forestlands are severely fragmented, connectivity values are lost, and forest landscape restoration is needed for conservation and functional green infrastructure.

Keywords Boreal · Forest connectivity - Green infrastructure - Landscape transformation - Continuity forests $\cdot$ Sweden

\section{Introduction}

With $70 \%$ and more of the earth's land surface (Barnosky et al. 2012) and 80\% and more of remaining forests (Watson et al. 2018) modified by land use, the Anthropocene human footprint immensely influences key ecological functions, habitat characteristics, ecosystem services and biodiversity (e.g., Venter et al. 2016; Tucker et al. 2018). Forests are subject to extensive logging worldwide that, beyond relocating natural forest frontiers, also affects the functionality of protected areas, remaining primary forests and intact forest landscapes (Heino et al. 2015; Potapov et al. 2017; Jones et al. 2018; Sabatini et al. 2018). The consequences of forest fragmentation and loss are increasingly debated on global scale and for many forest regions (e.g., Defries et al. 2010; Hansen et al. 2013; Watson et al. 2018). In the boreal biome, natural configuration of forest landscapes are seriously transformed by rotation forestry systems that, amongst other impacts, interrupt spatial connectivity and temporal continuity of forest cover (e.g., Boucher et al. 2009; Svensson et al. 2018). Given the circumpolar range, large area and rich ecological values in the boreal biome (e.g., Moen et al. 2014) this transformation profoundly impacts a globally important biodiversity and ecosystem services source, disturbs ecosystem resilience to climate and land use changes (Mantyka-Pringle et al. 2012; Blumroeder et al. 2019), and contests sustainability- and conservation-oriented policies and environmental targets (Sverdrup-Thygesson et al. 2014; Chazdon et al. 2016; IPBES 2018; Angelstam et al. 2020). In combination with climate change, intensive forestry and other drivers of ecosystem change, a sledgehammer effect is foreseen where boreal ecosystems as well as ecosystems in other biogeographic regions are at risk of entering new and potentially irreversible ecological states (Barnosky et al. 2012). Besides a need for larger areas of protected forests (e.g., EC 2020) there is also a strong movement towards increasing forest cover, forest landscapes and ecosystem restoration (Aerts and Honnay 2011), as expressed in the UN Declaration of Ecosystem Restoration (UN 2019). Accordingly, remaining primary forests, old-growth forests and intact forest landscapes needs to be identified, mapped and assessed regarding threats to and opportunities for maintaining their ecological status (Potapov et al. 2017; EC 2020).

The exploitation pressure in many regions remains high even in the last intact forest landscapes (e.g., Potapov et al. 2008; Chazdon et al. 2017; Müller et al. 2018; EC 2020). In Europe, with a long and intensive land-use history, intact forest landscapes are very rare and those remaining deserve particular attention (e.g., Wallenius et al. 2010). Intact forest landscapes are defined as larger $\left(>500 \mathrm{~km}^{2}\right)$ mosaics of forests and natural open ecosystems that include primary forests that show no or low influence of human activities and habitat fragmentation, but where some historic human influence of, e.g., preindustrial selective logging, may have occurred (Potapov et al. 2008, 2017). Primary forests are defined as naturally regenerated forest with native tree species where there are no clearly visible signs of human influence and where the ecological processes are not significantly disturbed (FRA 2020). It is also increasingly accepted that effective nature conservation will have to move beyond passive protection of remaining high conservation value forests into complementary active restoration of transformed forest areas on both stand and landscape level through advanced conservation-oriented management strategies and practices (e.g., Kuuluvainen 2009; Stanturf et al. 2014; Spathelf et al. 2018). Hence, attention is simultaneously directed to the distinct values of primary forests, large, contiguous and intact forest landscapes, and to promoting a sustainable, holistic, multiple-scale and multiple-use spatial landscape governance and management (Sayer 2009; Arts et al. 2017; Sabatini et al. 2018). 
The concept of green infrastructure, which as a fervent EU initiative is integrated into one or more policy sectors in all member states (Slätmo et al. 2019), aims to secure biodiversity, habitat resilience and ecosystem services at multiple spatial scales (Liquete et al. 2015). Thus, green infrastructure promotes landscape-scale and holistic planning based on known conservation core areas and their functional connectivity in the existing matrix, as, for example, the Yellowstone to Yukon Conservation Initiative in North America (Mahr 2007) and the Australian Alps to Atherton Connectivity Conservation Area (Pulsford et al 2010). In practice this implies that green infrastructure requires a spatio-temporal perspective ranging from local species occurrence and microsites, to habitats, landscapes and entire regions (e.g., Heller and Zavaleta 2009; Gustafsson et al. 2012). Furthermore, a functional green infrastructure intrinsically relies on a continuum of intra- and inter-connected land cover types and their transitions, temporal landuse changes, natural succession and dynamics, and also restoration of transformed matrix surrounding the core areas (Sayer 2009; Chazdon et al. 2016; Chazdon 2018). Hence, for green infrastructure focusing on forest ecosystems, intact forest landscapes play a paramount role. The landscape-scale and holistic approach in the green infrastructure concept is recognized in the Aichi target 7 on sustainable management, biodiversity and conservation in target 11 on setting aside a minimum of $17 \%$ of terrestrial areas, and in target 15 on restoring degraded ecosystems (CBD 2010). Although frequently promoted, however, landscape approaches aiming for advanced nature conservation are often not successful in practice and hence need to be further developed (e.g., Chazdon et al. 2017; IPBES 2018).

Intact forest landscapes support globally significant ecological legacies (e.g., Potapov et al. 2017; Watson et al. 2018; Jonsson et al. 2019) because of maintained ecosystem structures and function, continuous forest cover, old-growth forest habitat attributes and continuity of natural dynamics including disturbance processes and successions. The actual functional size and spatial configuration of the forest patches is important to consider when discussing their functionality as habitat. A basic assumption is that the center of intact forest patches harbors higher intrinsic natural values than the periphery, and thus that the distance to edges and influences from the surrounding matrix is a critical factor (e.g., Riitters et al. 2016; Pfeifer et al. 2017). On global scale, Haddad et al. (2015) found that $70 \%$ of the remaining primary forest areas are within $1 \mathrm{~km}$ and $50 \%$ within $500 \mathrm{~m}$ from forest edge, and that a predominance of remaining intact forest fragments are only 10 ha or less in size. On national scale-for Sweden-Esseen et al. (2016) found that forest edge towards clearcuts was the most common type of edge below the mountain region. Thus, identification, mapping and spatial assessment of remaining intact forest landscapes is critically important. In their global-scale analysis, Potapov et al. (2008) identified three intact boreal forest landscapes on the Fennoscandian shield (i.e., Norway, Sweden, Finland and Northwest Russia); the forest belt on the Swedish side of the Scandinavian Mountain Range, the forest border-area between Finland and Northwest Russia, and the Kola Peninsula forest belt. These intact forest landscapes were also identified by Watson et al. (2018) as among the last remaining wilderness areas. Of these, only the Scandinavian Mountain range forest belt is entirely within the European Union (Jonsson et al. 2019).

This study is focused on primary forest and intact forest landscapes in boreal and subalpine Sweden and in particular on the remaining natural and near-natural forests and woodlands in the foothill's landscapes along the east slopes of the Scandinavian Mountain Range. The holistic spatial dimensions of this truly extensive intact forest landscape has previously not been studied in greater detail and its significance for the entire regional-scale boreal biome has not been assessed. Our study thereby complements and deepen earlier research on intact forest landscapes at pannational and global scales, such as those by Hansen et al. (2013) and Potapov et al. (2008, 2011) on remaining intact forest landscapes, and by Heino et al. (2015) on forest loss in protected and intact forest areas. This study contributes a regional-scale assessment of forest and forest landscape intactness and connectivity, at a resolution that allows for input to green infrastructure planning, and as such a case study approach to applied landscape ecology.

Our study objectives were to analyze areal and density distribution, contiguous forest-cluster size and spatial distribution and connectivity attributes, of primary forest relative to all forestland and to existing protected areas. Thus, a generic assumption is that such forests maintain, or potentially maintain, forest 
and forest landscape attributes that are lost or disturbed by extensive clearcutting practices elsewhere in the landscape (cf. Curtis et al. 2018; Blumroeder et al. 2019). Our study covered a 22.2 million ha forest-dominated region, pre-dominantly with extensive rotation forestry impacts. The input data consisted of forests that have not been harvested since the 1950 s to 1960 s, which broadly covers the rotation forestry era in the region (Lundmark et al. 2013; Jonsson et al. 2019). We simultaneously provide a comprehensive regional spatio-temporal impact assessment of rotation forestry resulting in severe loss and fragmentation of intact forest landscapes, and assess the spatial patterns and connectivity of the Scandinavian mountains "green belt" (sensu Terry et al. 2006). The forestland in the Swedish mountain region is currently a subject of a heated debate concerning a continued conservation and small-scale governance and management direction, or a direction towards more intensive forestry (Jonsson et al. 2019). This debate is one of many debates on the same theme worldwide (e.g., IBPES 2018). Our results are discussed in the context of strategic and operational prospects to address forest green infrastructure functionality in boreal forest landscapes, as a way forward to mitigate the negative consequences of forest fragmentation and loss.

\section{Materials and methods}

Study region

The study region (22.2 million ha land area; SLU 2018) extends from the southern boreal Gulf of Bothnia coast to the northern boreal and alpine tree line of the Scandinavian Mountain Range (Gustafsson and Ahlén 1996) (Fig. 1). To assess differences within this large and diverse study region through patternoriented analyses, we divided it into nine sub regions (SR hereafter). Forests covers 14.5 million ha (see Table 1) which equals over $50 \%$ of all forest land and over $60 \%$ of the boreal forests in Sweden (Esseen et al. 1997; SLU 2018). Noteworthy, the forest area in the study region is equal to about $20 \%$ of the all forest land in northern Europe (Forest Europe 2015). Scots pine (Pinus sylvestris) is the dominant tree species with $44 \%$ of the total productive forest area (tree growth $>$ $1 \mathrm{~m}^{3} /$ ha/year on average over a 100 year rotation period; excluding formally protected forest), followed by Norway spruce (Picea abies) with $23 \%$ (SLU 2018). The subalpine mountain birch (Betula pubescens ssp. czerepanovii) covers about 970,000 ha in the study region, equal to more than $95 \%$ of its total cover in Sweden (Hedenås et al. 2016).

The study region includes gradients in latitude and altitude with associated species distributions patterns, in rotation forestry duration and degree of impact, and in forest landscape configuration and productivity from more fertile forest sites in the south and east to poor woodland sites at higher altitudes in the north and west. The forest management history can be traced back to the $1600 \mathrm{~s}$ with more pronounced exploitation since the mid-1800s (Lundmark et al. 2013). Although forest harvesting, dimension cuttings and selective thinning have occurred for centuries (Esseen et al. 1997; Östlund et al. 2015), the most extensive and systematic impacts have taken place during the last 60-70 years with the onset of widespread rotation forestry (Ecke et al. 2013; Moen et al. 2014; Peura et al. 2018). In addition to removing all or most trees and shrubs over large areas, soil scarification, replanting with non-native and modified genotypes in monocultures, draining and road infrastructure development, have resulted in a seriously transformed landscape dominated by plantation forests, planted forest and naturally regenerated forests (FRA 2020). Hence, this industrial forestry system has caused cumulative impacts on forest ecosystems uniformly and systematically across site types and over large areas. Ecosystem legacies are disrupted and continuity values have been lost (Svensson et al. 2018).

\section{Data}

The data represents a publicly available, high-resolution $(10 \times 10 \mathrm{~m}$ raster $)$, complete and consistent mapping of forests that have not been clear cut, developed, compiled and validated by Metria $\mathrm{AB}$ on commission by the Swedish Environmental Protection Agency (Ahlcrona et al. 2017a) for the entire boreal biome in Sweden. The mapping was performed as an automatic retrospective change detection analysis of satellite images from 1973 to 2016 and aerial photos from the 1950s and 1960s. The starting reference year for detecting the earliest clear cuts and young artificially regenerated forests was set to $1960 \pm 5$ years as an average across the region. All forest patches 0.5 ha 


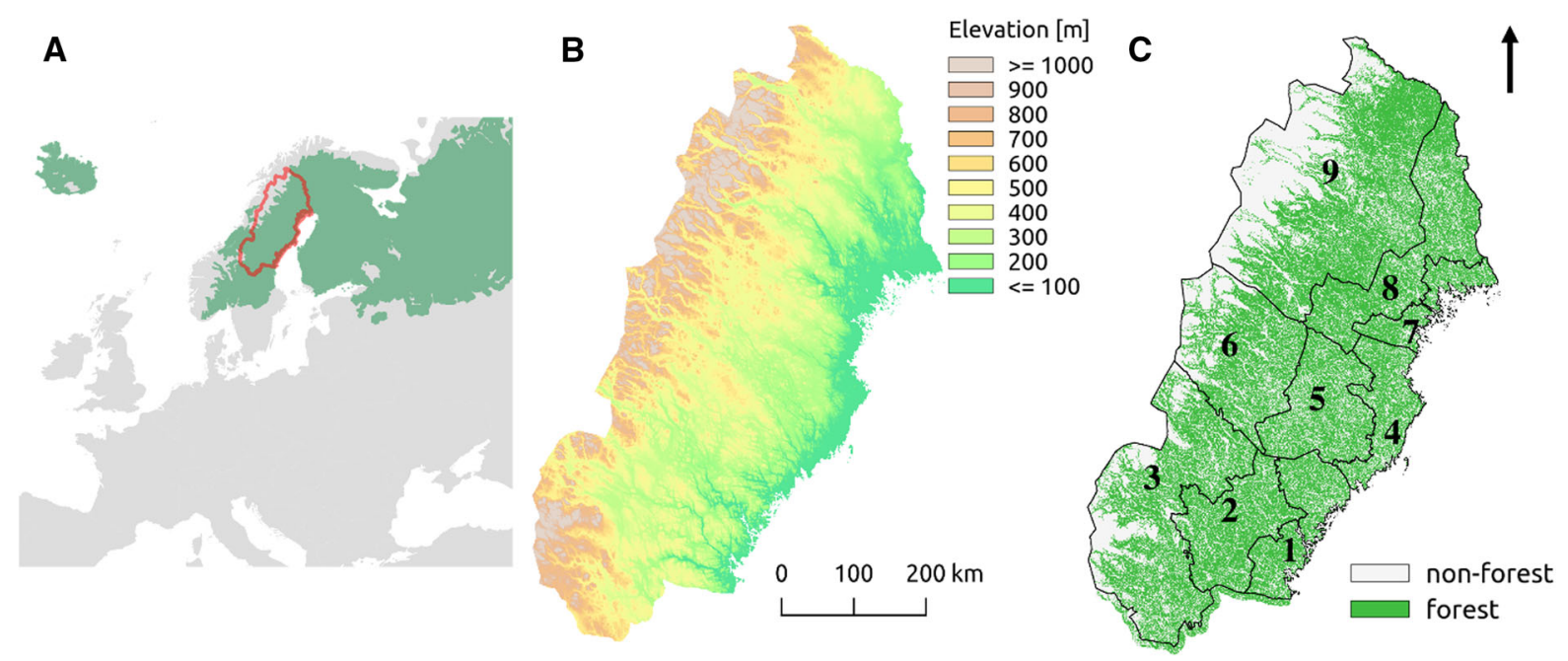

Fig. 1 a The location of the study region in Europe (red line) with the extension of the boreal biome highlighted in green. b The elevation (m) above sea level across the study region calculated from the elevation model. c Total forest land (green) with the nine analysis sub-regions; (1) South coastal, (2) South inland, (3) South mountain, (4) Central coastal, (5) Central inland, (6) Central mountain, (7) North coastal, (8) North inland, (9) North mountain. The subregions were divided by counties south (Västernorrland and Jämtland), central (Västerbotten) to north (Norrbotten) and by municipalities in zones east to west. The coastal zone covered all $(n=13)$ municipalities that border the Gulf of Bothnia east coast, the inland zone covered all municipalities $(n=18)$ not bordering the coast and the mountains, and the mountain zone all $(n=13)$ municipalities in the Scandinavian mountain range

Table 1 The area (in 1000 ha) of total forest land (TFL) with its proportion of formally protected forest (FPF), and the area of proxy continuity forest ( $\mathrm{pCF}$ ) with its proportion of total forest land and of formal protected forest, presented for the 9 subregions

\begin{tabular}{|c|c|c|c|c|c|}
\hline \multirow[t]{2}{*}{ Subregions } & \multicolumn{2}{|c|}{ Total forest land (TFL) } & \multicolumn{3}{|c|}{ Proxy continuity forests (pCF) } \\
\hline & Area (kha) & FPF $(\%)$ & Area (kha) & TFL $(\%)$ & $\operatorname{FPF}(\%)$ \\
\hline 1 South Coastal & 965 & 1.9 & 444 & 46.0 & 3.3 \\
\hline 2 South Inland & 1313 & 1.4 & 447 & 34.1 & 3.1 \\
\hline 3 South Mountain ${ }^{a}$ & 2481 & 8.6 & 1413 & 57.0 & 12.6 \\
\hline 4 Central Coastal & 829 & 1.5 & 419 & 50.5 & 2.2 \\
\hline 5 Central Inland & 1284 & 2.0 & 459 & 35.8 & 4.5 \\
\hline 6 Central Mountain ${ }^{\mathrm{b}}$ & 1567 & 22.8 & 1076 & 68.7 & 29.4 \\
\hline 7 North Coastal & 575 & 1.8 & 332 & 57.8 & 2.6 \\
\hline 8 North Inland & 1861 & 4.4 & 1002 & 53.9 & 6.7 \\
\hline 9 North Mountain ${ }^{c}$ & 3659 & 36.7 & 2752 & 75.2 & 39.5 \\
\hline Total & 14,532 & 14.3 & 8345 & 57.4 & 20.5 \\
\hline
\end{tabular}

${ }^{\mathrm{a}} 190,000$ ha mountain birch forest, equal to $8 \%$ of TFL and $13 \%$ of the pCF-area

$\mathrm{b}_{40,000}$ ha mountain birch forest, equal to $3 \%$ of TFL and $4 \%$ of the pCF-area

${ }^{\mathrm{c}} 740,000$ ha mountain birch forest, equal to $20 \%$ of TFL and $27 \%$ of the pCF-area. The Mountain birch estimates are presented in Online Appendix S3

and larger and forest belts $20 \mathrm{~m}$ or wider were identified and registered. For comparison, the average size of clearcuts in Västerbotten county, located in the middle of our study area, has been estimated to 14.1 ha and 7.2 ha in 1960 and 2010, respectively (Nordström 2017). The mapping had the highest precision in the central and northern part of the boreal biome (Ahlcrona et al. 2017a), which is included in this 
study. Based on validation against independent data derived from the Swedish National Forest Inventory, the stand age of not clear-cut forests varied between 120 and 144 years and the precision accuracy for stand age varied between 90 and $93 \%$ for $\geq 70$ year and between 76 and $86 \%$ for stand age $\geq 120$ years (Ibid.). The south part of the boreal biome (i.e. Dalarna and Gävleborg counties) where the mapping has a lower precision (94-123 years, $84 \%$ to $90 \%$, and $75 \%$ to $80 \%$, in comparison to the above), was not included. A feasibility study (Ahlcrona et al. 2017b) in the southeast parts of the study region indicates that a fraction of the data includes forest areas that were harvested too early to be detected, forest with a tree cover too low to be detected as forests, and forests with traces of forest management. The resulting overestimation of not clear-cut forest is mainly to be expected along the coast and river valleys where a longer and more tangible land use history have taken place (Svensson et al. 2018). In recognizing that the data is remote-sensing generated, we term the detected not harvested forest patches "proxy continuity forests" (pCF hereafter) following Svensson et al. (2018) and corresponding to proxies of primary forests (FRA 2020). More details about the entire pCF-data generation process and validation can be found in the supplementary material.

Auxiliary data sources include raster layers of forest cover (TFL hereafter, i.e. total forest land area) and the digital elevation model, both acquired from Copernicus (2018). The data on formally protected forests (FPF hereafter) were acquired from the Swedish Environmental Protection Agency (2018), and the mountain forest border from the Swedish Forest Agency (2018). The mountain forest border (SCB 2019) was established in the Swedish forest policy in 1991 and delineate the subalpine foothills forest landscape, wherein stricter regulation of forest harvesting is applied in current national forestry and environmental policies (Jonsson et al. 2019).

\section{Analyses}

In the first step, all spatial datasets including the original $10 \times 10 \mathrm{~m}$ pCF-raster were imported to and preprocessed using the GRASS GIS software (Neteler et al. 2012 Ver. 7.4.0). Next, to reduce the complexity of the analysis we re-sampled the original pCF-raster (81.3 million pixels) to a coarser grid using mode- based aggregation, and selected $50 \mathrm{~m}$ resolution (0.25 ha; 3.3 million pixels) as an appropriate tradeoff that allowed efficient computation and at the same time did not change the spatial structure of the original data. All maps were created using the open source software QGIS (QGIS Development Team 2017 Ver. 2.18). Supporting analyses information is provided in Online Appendices 1 and 2.

To visualize and numerically describe the spatial pCF-patterns for the nine SRs, we performed a moving window analysis using GRASS GIS and Python library SciPy (Oliphant 2007) that generated an output raster data on the proportion of pCF within a 1,25 and $100 \mathrm{~km}^{2}$ moving window centered on each pixel. To compare the mean and differences in $\mathrm{pCF}$ patterns between the SRs, we first selected all pixels with forest cover $\geq 75 \%$, and then used this subset to randomly sample pCF-density in 1000 pixels for each SR. This approach allowed us to account for differences in landscape configuration between sub-regions, to focus on those parts of a landscape that are dominated by forest, and to generate reliable numerical comparison between the SRs.

Further, we defined a pCF-cluster as a contiguous area of $50 \mathrm{~m}$ pixels with $\geq 50 \%$ pCF-cover within a 1 $\mathrm{km}^{2}$ window, and identified contiguous pCF-clusters of $\geq 10, \geq 100, \geq 1000$ and $\geq 100,000$ ha in size. The size of the window corresponds to the findings by Haddad et al. (2015), who established that $70 \%$ of the remaining intact forest are within $1 \mathrm{~km}$ from forest edge. We consider a pCF-cluster as a basic spatial unit that is dominated (i.e. $>50 \%$ within a $1 \mathrm{~km}^{2}$ ) by primary forests and supporting mature and older forests, which represents intact forest landscape. By using a $1 \mathrm{~km}^{2}$ window around each pCF-pixel and the majority rule to define a pCF-cluster together with the applied minimum patch-size rule (e.g., 25 ha for the connectivity analysis), we assured that only the least fragmented patches of intact forest landscapes were taken into account in our analysis, excluding the smallest patches $(<10$ ha) which can be considered as spatial noise in the data.

To assess the connectivity between pCF-clusters, we used a connectivity model derived from circuit electric flow theory (McRae et al. 2008) and implemented in the Circuitscape software (2018 Ver. 4.0.5). Circuitscape modeling is used in conservation planning for assessing ecological connectivity and is predicted to be an increasingly important tool for 
researchers and practitioners (Dickson et al. 2019) as well as for analyzing connectivity in fragmented landscapes (McGuire et al. 2016). Since we were aiming at modeling overall ("global", i.e. for the entire study region) connectivity and at assessing how connectivity differs between the SRs, we followed a method by Koen et al. (2014) that is insensitive to the placement of source and destination nodes and that does not require a selection of a focal species or independent data. To adjust to computational limits, we further down-sampled the pCF-raster from the $50 \times 50 \mathrm{~m}$ resolution to $500 \times 500 \mathrm{~m}$ resolution prior to running the Circuitscape algorithm. As we analyzed the global patterns and as coarsening the input grid usually generates results that closely approximate those generated at fine-scale resolution (i.e. Circuitscape is robust to scale change; see McRae et al. 2008), we foresee no detectable effects of this broader resolution on the final results and conclusions. We considered two land-type classes when designing the Circuitscape resistance surface; pCF-clusters $\geq 25$ ha (resistance value 1 ), and non-forest and clear-cut forest areas surrounding these (resistance value 100), respectively. The resistance values were chosen to assure contrast without influencing the connectivity distribution results, with reference to, e.g., the "one-stage expert approach" (Zeller et al. 2012) and customary approaches to assign increasing resistance values when empirical data is unavailable (Koen et al. 2014; Braaker et al. 2014).

The measure of connectivity used was cumulative current density (CCD), estimated for each pixel of the resistance surface raster. The estimated $\mathrm{CCD}$ values resulted from the connectivity (current flow) between all pairs of 24 focal nodes (552 combinations) randomly placed along the perimeter of a $50 \mathrm{~km}$ buffer zone around the study region, following the approach by Koen et al. (2014). We summarized the CCD-results for each SR using four quantile-based connectivity classes; $<0.25$ (low), $\geq 0.25$ (moderate), $\geq 0.50$ (high) and $\geq 0.75$ (highest), with the latter class corresponding to the most important connectivity "pinch points" (McRae et al. 2008). Finally, for each pCF-cluster, we estimated the areaweighted connectivity score (AWCS) following Dickson et al. (2013); defined as the sum of the cumulative current flow across all pixels in each pCF-cluster divided by its area. The AWCS thus detects the connectivity contribution based on both the size and the spatial location of individual clusters.

\section{Results}

The total forestland area was estimated to $14,532,000$ ha with the largest share $(53 \%)$ in the mountain SRs combined, and in particular large in the north mountain SR (Table 1). In total $14.3 \%$ $(2,078,000 \mathrm{ha})$ is formally protected, with the largest proportion $(59.5 \%)$ in the central and north mountain SRs combined. For the inland and coastal SRs, the protected proportion ranges from only 1.4 to $4.4 \%$. The pCF-area was estimated to 8,345,000 ha with the largest areas in the mountain SRs and the lowest in the coastal SRs. The pCF-proportion of total forestland was $57.4 \%$ and ranged from $75.2 \%$ in the north mountain SR to $34.1 \%$ and $35.8 \%$ in the south and central inland SRs, respectively. The proportion of protected pCF was $20.5 \%$ (1,711,000 ha), i.e. higher than the protected proportion of total forest land for the study region, and further also higher than on total forest land in each of the SRs. Generally, the proportion of protected $\mathrm{pCF}$ was highest in the mountain SRs, in particular the north mountain SR, and lowest in the coastal SRs and the south and central inland SRs. Mountain birch covers a substantial fraction of the forest and woodland in the mountain SRs. The estimates indicate in total 970,000 ha mountain birch forest, covering $7 \%$ and $12 \%$ of total forest land and pCF-area, respectively, with the highest estimates in the north and the lowest in the central mountain SR.

The moving window analyses (Fig. 2) detected a contiguous pCF-cluster pattern in the northern parts of the mountain range, and a more fragmented pattern in the south and central parts. For the $1 \mathrm{~km}^{2}$ window, areas with high pCF cluster density $(>50 \%)$ were found scattered in the north inland and in the coastal SRs, but for the $25 \mathrm{~km}^{2}$ and even more so for the 100 $\mathrm{km}^{2}$ window, high cluster density was almost solely detected in the mountain SRs. The increase in searchwindow size step-wise withdrew pCF-clusters in the inland and coastal SRs to the east, but also isolated pCF-clusters on higher altitudes to the west; i.e., the belt with a concentration of high pCF-cluster density was sequentially delimited. The median density was highest in the north mountain SR for all window sizes, 




Fig. 2 The study region with per cent proxy continuity forest (pCF) shown in a continuous scale where areas dominated by pCF are highlighted in green. The maps are based on a $1 \times 1 \mathrm{~km}, 5 \times 5 \mathrm{~km}$ and $10 \times 10 \mathrm{~km}$ moving window analyses centered on each $50 \times 50 \mathrm{~m}$ pixel. The boxplots are based

and lowest in the south inland SR for the $1 \mathrm{~km}^{2}$ and 25 $\mathrm{km}^{2}$ and in the central inland SR for the $100 \mathrm{~km}^{2}$ size. The pCF density variability increased with moving window size and from the coastal and inland SRs to the mountain SRs.

The pCF-cluster analyses (Table 2) revealed that pCF-clusters larger than 10,000 ha were found in all SRs, whereof as much as $91 \%(4,366,000$ ha) in the mountain SRs combined; equal to $81.5 \%$ of the total pCF-cluster area in the mountain SRs and $58.0 \%$ of all detected pCF-cluster area in the study region. The fraction of clusters larger than 10,000 ha in the inland SRs $(245,000 \mathrm{ha})$ is mainly parts of clusters that had their main location in the mountain SRs. In the coastal SRs, clusters larger than 10,000 ha covered about 149,000 ha. Medium size clusters ( $>100$ ha and $\leq 10,000 \mathrm{ha})$ dominated in the coastal and inland SRs. The actual proportion of pCF in the clusters on 1000 random samples of pCF-proportion of total forest land area, in areas with forest cover $\geq 75 \%$ for each sub region. The boxplots visualize the median, the first and third quartiles, 1.5 times the inter-quartile range, and all outlier points plotted individually

increased from the coastal $(69.4 \%)$ to the inland $(72.1 \%)$ and the mountain $(80.3 \%)$ SRs. Sequentially larger clusters thus included a larger proportion of $\mathrm{pCF}$, indicating lower fragmentation of pCF-patches within intact forest landscapes.

The geographical distribution of pCF-clusters (Fig. 3) shows that clusters $\geq 10,000$ ha exist almost only at higher elevations to the west of the mountain forest border, with a disrupted distribution in the middle part of the south mountain SR. Still, a considerable total area of clusters $\geq 10,000$ ha (644,000 ha in 23 clusters) was detected in the south mountain SR. Outside the mountain SRs, clusters $\geq 10,000$ ha were only found in scattered clusters in the north inland and coastal SRs. Clusters $\geq 1000$ ha were more frequent and occurred in a more contiguous pattern, in particular in the north SRs and within a narrow belt along the coast. 
Table 2 Proxy continuity forest (pCF) cluster area (in $1000 \mathrm{ha}$ ) and the actual pCF-proportion of the cluster area, presented in five cluster-size classes and in total, for coastal, inland and mountain zones. pCFclusters were defined as contiguous areas of pixels with $\geq 50 \%$ of proxy continuity forest (pCF) within a $1 \mathrm{~km}^{2}$ window. The pCF cluster numbers and class proportions, the cluster area and class proportions, the pCF area and class proportions, and the proportion pCF area of cluster area, are presented in Online Appendix S4 for all cluster size classes for all nine subregions (SR)

\begin{tabular}{|c|c|c|c|}
\hline Zones & Cluster size class (ha) & Cluster area (kha) & pCF proportion $(\%)$ of cluster \\
\hline \multirow[t]{6}{*}{ Coastal } & $\leq 10$ & 3.4 & 50.2 \\
\hline & $10-\leq 100$ & 53.4 & 69.0 \\
\hline & $100-\leq 1000$ & 282.5 & 69.8 \\
\hline & $1000-\leq 10,000$ & 316.4 & 69.4 \\
\hline & $\geq 10,000$ & 148.6 & 69.4 \\
\hline & Total & 804.3 & 69.4 \\
\hline \multirow[t]{6}{*}{ Inland } & $\leq 10$ & 5.2 & 51.4 \\
\hline & $10-\leq 100$ & 94.7 & 71.5 \\
\hline & $100-\leq 1000$ & 410.3 & 71.6 \\
\hline & $1000-\leq 10,000$ & 412.2 & 71.9 \\
\hline & $\geq 10,000$ & 245.5 & 73.8 \\
\hline & Total & 1168.0 & 72.1 \\
\hline \multirow[t]{6}{*}{ Mountain } & $\leq 10$ & 5.3 & 54.4 \\
\hline & $10-\leq 100$ & 85.7 & 71.8 \\
\hline & $100-\leq 1000$ & 397.1 & 73.1 \\
\hline & $1000-\leq 10,000$ & 414.9 & 75.3 \\
\hline & $\geq 10,000$ & 3972.3 & 81.8 \\
\hline & Total & 4875.4 & 80.3 \\
\hline
\end{tabular}

Clusters $>100$ ha and $>10$ ha are more frequent in the north inland and coastal SRs than in central and south inland and coastal SRs, with a pronounced loss also of these smaller size classes in particular indicated in the inland SRs.

Across the whole study region, high pCF-connectivity was detected in an elongated belt in the mountain SRs, and to a lesser and more scattered extent in the north inland and coastal SRs (Fig. 4a). In contrast, we documented very low connectivity in the south and central inland and coastal SRs, although with some scattered pCF-clusters with high AWCS values that, hence, represents key areas for the remaining connectivity in these forest landscapes (Fig. 4b). Clusters with low to moderate connectivity $(<0.50$ quantile) were detected in all SRs and dominated in the inland and coastal SRs, whereas the highest $(\geq 0.75)$ and high $(\geq 0.50$ and $<0.75)$ connectivity was largely confined to the mountain SRs (Fig. 4c, d). Connectivity in the central and south inland SRs was generally low with the highest connectivity class nearly absent.

For the coastal and inland SRs, the area and proportion of total forest land with low and moderate connectivity classes were found to be consistently larger than the area and proportion with high and highest connectivity (Table 3 ). In contrast, both area and proportion of the high and highest connectivity classes were larger in the south and north mountains SRs and the highest connectivity class larger in the central mountain SR, with 793,000 ha and a proportion of $21.7 \%$ of the highest connectivity in the north mountain SR as the largest values. A large fraction of protected pCF-clusters was found in the mountain SRs (Table 3), with the largest proportions equal to $47.7 \%$ and $46.7 \%$ of total forest land in the high and highest connectivity classes in the north mountain SR, respectively. In the mountain SRs, the lowest fractions of protected pCF-clusters, in those connectivity classes, were found in the south mountain SR (13.8\% and 22.4\%). This contrasts the inland SRs where the protected proportion of the high and highest connectivity classes varied between $4.9 \%$ (north) and $8.1 \%$ (south), and in the coastal SRs between $2.2 \%$ (central) and $4.2 \%$ (north).

There were important differences among the mountain SRs. The north mountain SR had the overall highest connectivity, i.e. the largest areas with pCFclusters of any connectivity class (Fig. 4; Table 3) and also a relatively even distribution of clusters across all connectivity classes. Both the central and south mountain SRs had areas with the highest connectivity class weighted to total forest land $(21.8 \%$ and $17.8 \%$, respectively) at comparable proportion to the north 

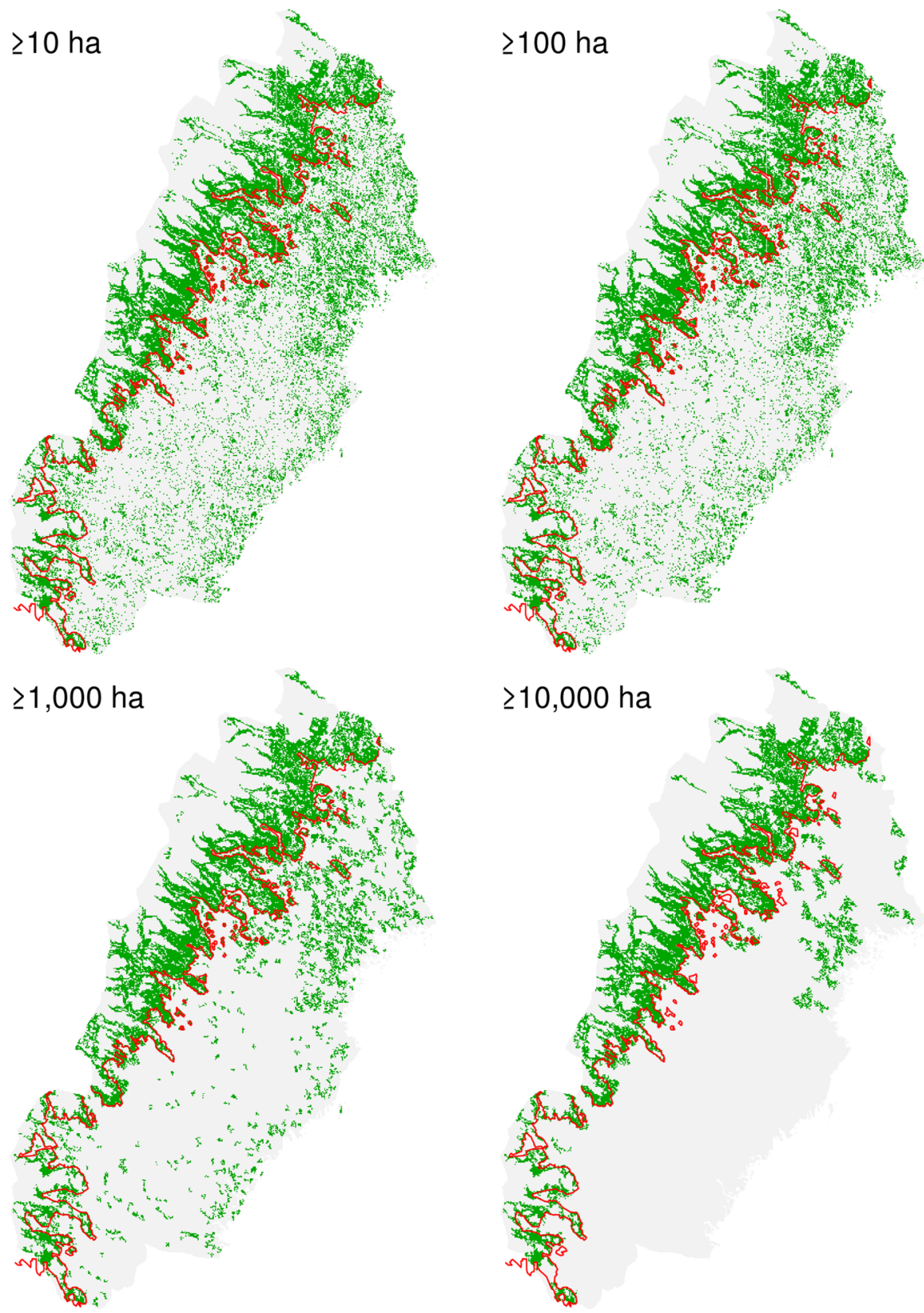

Fig. 3 The spatial distribution of the pCF-clusters (green) showed for clusters $\geq 10, \geq 100, \geq 1000$ and $\geq 10,000$ ha in size. Clusters were defined as contiguous areas of pixels

mountain SR (19.6\%). However, the weighted areas of low, moderate and high connectivity classes, especially the two latter, were much smaller which thus shows a skewed connectivity distribution. For the south mountain SR in particular, the overall

with $\geq 50 \%$ of proxy continuity forest (pCF) within a $1 \mathrm{~km}^{2}$ window. The red line presents the mountain foothills border (Swedish: "fjällnära gränsen")

connectivity within intact forest landscapes relies on the fraction of highest connectivity. 

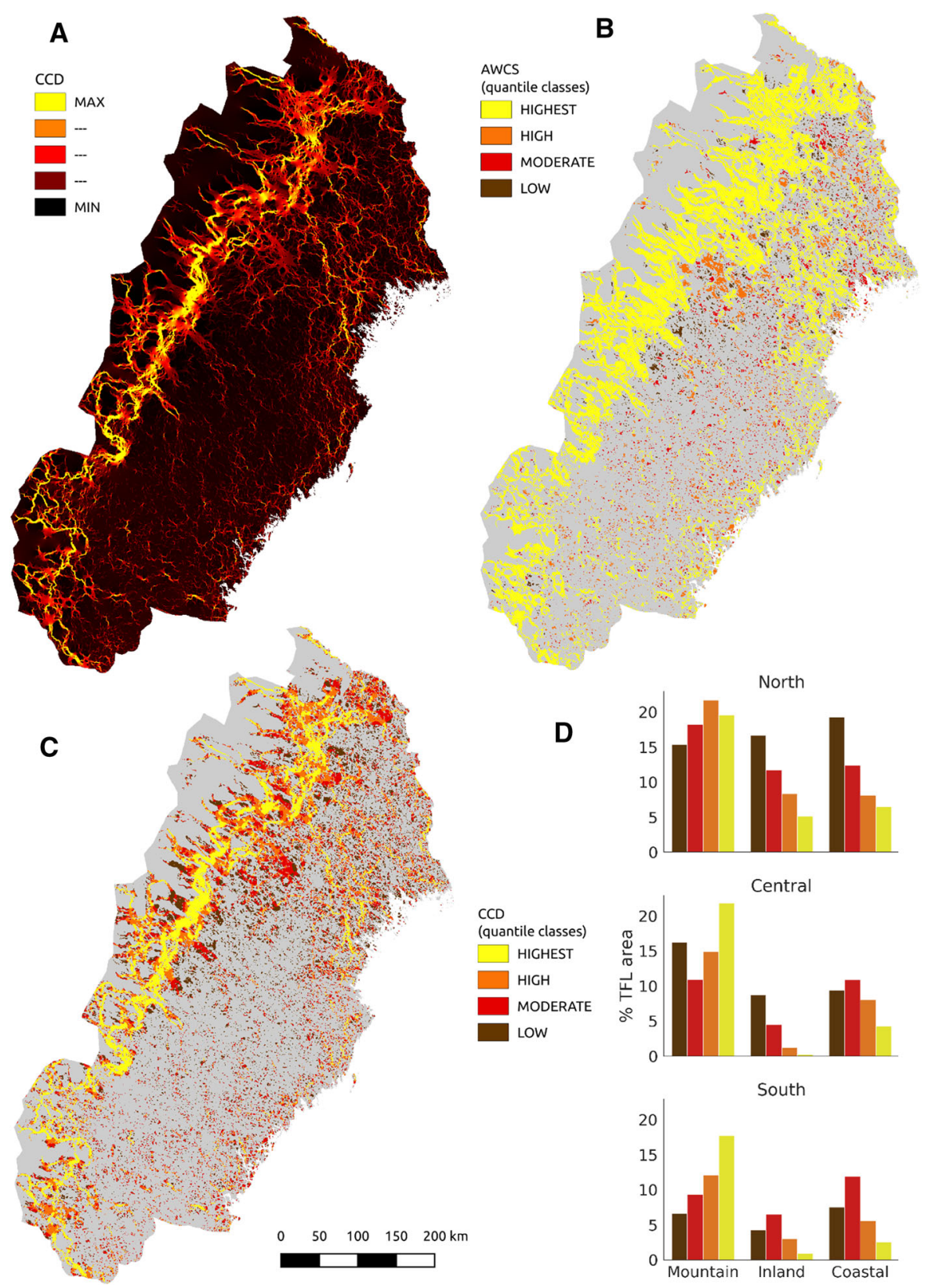

Fig. 4 a Cumulative current density (CCD) mapping illustrating the global connectivity between proxy continuity forest (pCF) clusters $\geq 10$ ha. The color scale from brown to red to orange and to yellow shows areas with subsequently higher current density. b pCF-cluster importance mapping derived from the area-weighted connectivity score (AWCS) estimated

\section{Discussion}

Intact forest landscapes are becoming rare globally and now occurs mainly in remote hinterland areas

for each pCF-cluster and presented in four quantile classes. Grey is masked non pCF and other land cover types than forest land, as also in c. c Cumulative current density (CCD) mapping presented in four quantile classes. d The CCD corresponding barplots shows, for each subregion, the proportion of given connectivity class of total forest land area in that subregion

(e.g., Hansen et al. 2013; Watson et al. 2018). Although the commonly-held view is that much of the forest landscape in Sweden has been largely transformed by forestry and other human influence 
Table 3 Summary of the global connectivity between pCFclusters $\geq 25$ ha measured as the cumulative current density (CCD) for each pixel of the resistance surface (see methods section and Online Appendix S1), presented in four quantile classes $(A)<0.25$, (B) $\geq 0.25,(C) \geq 0.50$, and $(D) \geq 0.75$, with the following statistics presented for the sub regions: pCFclusters area (in 1000 ha) per class, class proportion of total forest land (TFL), and class proportion of formally protected forest (FPF)

\begin{tabular}{|c|c|c|c|c|c|c|c|c|c|}
\hline & \multicolumn{3}{|l|}{ South } & \multicolumn{3}{|l|}{ Central } & \multicolumn{3}{|l|}{ North } \\
\hline & Coastal & Inland & Mountain & Coastal & Inland & Mountain & Coastal & Inland & Mountain \\
\hline \multicolumn{10}{|l|}{ Connectivity class 0 to $<25$} \\
\hline Area (kha) & 72.8 & 56.3 & 164.7 & 77.5 & 112.0 & 253.7 & 110.6 & 311.2 & 563.0 \\
\hline Proportion of TFL (\%) & 7.5 & 4.3 & 6.6 & 9.4 & 8.7 & 16.2 & 19.3 & 16.7 & 15.4 \\
\hline Proportion of FPF (\%) & 4.1 & 3.0 & 7.7 & 2.3 & 7.7 & 23.5 & 2.4 & 8.9 & 25.0 \\
\hline \multicolumn{10}{|c|}{ Connectivity class 25 to $<50$} \\
\hline Area (kha) & 115.1 & 85.5 & 231.0 & 89.8 & 57.4 & 170.8 & 71.4 & 218.5 & 665.9 \\
\hline Proportion of TFL (\%) & 11.9 & 6.5 & 9.3 & 10.9 & 4.5 & 10.9 & 12.4 & 11.7 & 18.2 \\
\hline Proportion of FPF (\%) & 5.1 & 5.6 & 9.3 & 2.0 & 7.2 & 30.2 & 2.6 & 10.6 & 38.5 \\
\hline \multicolumn{10}{|c|}{ Connectivity class 50 to $<75$} \\
\hline Area (kha) & 54.2 & 39.4 & 299.5 & 66.2 & 15.0 & 232.8 & 47.0 & 155.2 & 793.0 \\
\hline Proportion of TFL (\%) & 5.6 & 3.0 & 12.1 & 8.0 & 1.2 & 14.9 & 8.2 & 8.3 & 21.7 \\
\hline Proportion of FPF (\%) & 2.6 & 8.1 & 13.8 & 2.2 & 5.3 & 31.5 & 4.2 & 4.9 & 47.8 \\
\hline \multicolumn{10}{|l|}{ Connectivity class 75 to 100} \\
\hline Area (kha) & 24.8 & 12.4 & 440.6 & 35.5 & 3.2 & 341.3 & 37.3 & 95.8 & 716.5 \\
\hline Proportion of TFL (\%) & 2.6 & 0.9 & 17.8 & 4.3 & 0.2 & 21.8 & 6.5 & 5.1 & 19.6 \\
\hline Proportion of FPF (\%) & 2.4 & 3.8 & 22.4 & 2.1 & 13.3 & 38.8 & 2.7 & 3.3 & 46.7 \\
\hline
\end{tabular}

through time (Esseen et al. 1997; Pape and Löffler 2012; Moen et al. 2014; Östlund et al. 2015), the boreal to sub alpine forests and woodlands of the Scandinavian mountain range have been identified as one of very few remaining large, contiguous intact forest landscapes in Europe (e.g., Potapov et al. 2008). Our study reveals the unambiguous existence of a connected network of primary forests along the eastern foothills of the mountain range. More than half $(57.4 \%)$ of the forestland has not been clear-cut during the latest 60-70 year, with a particularly large fraction $(75.2 \%)$ remaining in the north. We documented high forest connectivity along the whole mountain stretch, with the exception of apparent connectivity gaps in the south part. This Scandinavian Mountains Green Belt extends for around $800 \mathrm{~km}$ straight-line distance south to north, i.e. for about half of the total length of the entire mountain range from the high arctic Nordkap to the southern boreal Stavanger in Norway. In light of climate change, this green belt, as other large intact forest landscapes, can be assumed to harbor capacity and resilience to adapt to changes and provide critical northward dispersal, migration and connectivity routes for species, habitats, and ecosystem processes and services (e.g., Elmhagen et al. 2015; Jansson et al. 2015; McGuire et al. 2016).

We have applied the term "green belt" for the intact Scandinavian Mountain range forest landscape. The Green Belt initiative is one of several initiatives to promote conservation of significant ecologically functional networks of protected areas and bridging links. The initiative was launched by the IUCN (Terry et al. 2006), to contribute to, e.g., the implementation of the EU Habitats Directive. In this study, we confirm the existence of such quality characteristic for a forest landscape green belt along the east slopes of the Scandinavian mountain range.

There is rich evidence that intact forest landscapes and generally old forests support globally significant environmental values, such as native biodiversity, carbon sequestration and storage, fresh water provision, but also indigenous cultures (Watson et al. 2018; Thom et al. 2019). In this light, we argue that the maintenance of the Scandinavian Mountains Green 
Belt is of highest international interest, both for efficient nature conservation and for the achievement of long-term sustainability in fragile, hinterland regions of the European north. We also argue that it, as other intact forest landscapes, are invaluable assets as key components in establishing an functional green infrastructure in Europe and elsewhere (cf. Liquete et al. 2015; Slätmo et al. 2019) as well as represents an unique reference area for basic and applied research (Kuuluvainen et al 2017). A recent study by Hermoso et al. (2020) concerning EU's Green Infrastructure Strategy underscored the importance of supra-national planning as often being superior to national and subnational planning. We argue that the Scandinavian Mountains Green Belt, in this perspective, is to be understood as a core component for green infrastructure in the European boreal forest region.

The forest landscapes of the European north are dominated by systematic clear cutting rotation forestry and thus have undergone extensive transformation (e.g. Peura et al. 2018). Data that allows change detection of how, where and to what extent this transformation have influenced the natural landscape configuration, such as the data applied in this study, are very valuable. Detailed spatial analyses of remaining intact forest landscapes and primary forests on local and regional scale, clearly fill a knowledge gap for national (e.g., Angelstam et al. 2020) and European and other pan-national contexts (e.g., Sabatini et al 2018), beyond adding functional dimensions to green infrastructure planning. Similar approaches in other European regions, and potentially also for other landcover types than forests, would provide a much needed supra-national perspective on functional green infrastructure assessments (Slätmo et al. 2019; Hermoso et al. 2020).

The Swedish mountain foothills forest landscapes remain in a natural and near-natural state, including very large ( $\geq 10,000$ ha) contiguous forest components. Although various historical land uses including preindustrial tree harvesting has influenced forest stand and landscape configuration, high nature conservation values still subsists-as clearly expressed in the large proportion of already protected forests and the intrinsic conservation values registered in the national woodland key habitat inventory and national forest inventory (Jonsson et al. 2019). As of December $2018,56.3 \%$ of all forest land and $52.5 \%$ of the productive forest land above the mountain forest border is formally protected (SCB 2019). However, as established in this study, there are also large areas of primary forests that currently are not protected. A combination of additional protection, landscape restoration and high-ambition nature conservation considerations, can indeed contribute to improved connectivity and functional green infrastructure. It is well established that managed forests can be restored, matrix quality can be improved and that such measures will support functional connectivity (e.g., Heller and Zavaleta 2009; Dondina et al. 2017; Chazdon 2018). Maintaining, and where possible restoring, intact forests, is thus of urgent priority to current global efforts for halting biodiversity loss, mitigate adaptive ecosystem capacity to climate change and to achieve sustainability goals (e.g., Watson et al. 2018; UN 2019; EC 2020). The biotic gradients in the northern boreal to alpine transition, alongside with the natural habitat fragmentation, habitat-type transition zones and land-cover heterogeneity, provide a diversity of ecosystems and their services (Grĕt-Regamey et al. 2012; Blicharska et al. 2017). If governed and managed in a sustainable way and according to current conservation policies, the Scandinavian Mountains Green Belt can play a key role in European conservation policy far into the future.

In contrast to the mountain foothills forest landscape, the inland and coastal areas, in particular in the central and south parts encompassing about 4.4 million ha, are extensively modified by rotation forestry. Here, only fragments of the forest landscape have escaped clear cutting and transformation into artificially regenerated forests. Our results show, however, that some forest connectivity remainsalbeit at lower levels, in particular in the north part of the study region in a geographically semi-connected network from the mountains across the inland to the coast and further south along the coast. The remaining clusters are few and scattered, but are still important for the local connectivity and generally also as components supporting functional green infrastructure on larger scales (Svensson et al. 2018).

The strongly modified inland and coastal landscapes emphasize the importance of maintaining the Scandinavian Mountains Green Belt, as it can serve as a mainland source to support re-colonization and reestablishment of natural forest ecosystem processes, species, biodiversity, ecosystem services and climate change adaptive ecosystem capacity. Thus, its 
continued existence is essential for the "global" connectivity in boreal Fennoscandia and northern Europe. Furthermore, an interesting feature is the indigenous Sapmi people reindeer (Rangifer tardanus) husbandry that is an ongoing land use across the whole study region, alongside with and on the same land as forestry and other land uses (Sandström et al. 2016). As a note, the definition of primary forests (FRA 2020), which is applied in this paper, recognizes the existence of indigenous peoples and their culture as part of intact forest landscapes and other wilderness areas (e.g. Watson et al. 2018). The traditional seminomadic reindeer husbandry system includes annual migrations from the mountain area in the summer season to the inland and coastal areas in the winter season. This migration relies on connected reindeer movement routes and on continuous grazing access to ground and arboreal lichens in relatively open forests with mature and old trees (Pape and Löffler 2012). Thereby, an expansion of intact forest networks to the inland and coastal areas through directed forest stand, landscape and ecosystem restoration, will support also this internationally significant indigenous culture that exists across the European north in Norway, Sweden, Finland and Northwest Russia. That is, a green infrastructure planning and implementation that maintain and expand forest connectivity with the Scandinavian Mountains Green Belt as an axis component, will support multiple ecosystem and landscape values and services across a very large region.

For the mountain and northernmost parts of the study region, a proportion of the intact forest consists of subalpine mountain birch. Notably, the density analysis step-wise omitted smaller, isolated and elongated forests and woodlands in high altitude mountain valleys dominated by mountain birch. Thus, the main connectivity route was concentrated to larger, more contiguous, and more coniferous dominated forests. The highest connectivity was detected in the central mountain SR where the proportion of mountain birch forest was estimated to be the lowest. This partly indicates that connectivity there largely is associated with coniferous forests but also is the effect of our assumptions for a connectivity analysis (i.e. that only larger contiguous forest clusters were taken into account) and our definition of an intact forest landscape cluster (see the methods section). By contrast, the connectivity in the north mountain SR is associated with a higher share of mountain birch forests, in a landscape characterized by large mires, rocky outcrops, etc., land without or with low cover of trees (SLU 2018). This mosaic landscape naturally implies a lower level of natural forest connectivity, as detected in this study. However, it is also assumed that limited accessibility for forestry and already large protected areas explains the patterns in the north SR. Thus, our connectivity analysis is found to be sensitive to differences in natural landscape configuration. However, it should be stressed that open and semiopen forests on both productive and non-productive forest land can harbor significant continuity values (Hemäläinen et al. 2017) and hence contribute to functional green infrastructure.

There is an increasing interest in identification of remaining intact and wilderness forest areas on pannational and global scales, and there is a critical need for policy recognition and protection of such areas. Recent publications include for example Haddad et al. (2015), Heino et al. (2015), Potapov et al. (2017), Jones et al. (2018), Müller et al. (2018) and Watson et al. (2018). Our study contributes precision and resolution in one of those areas that have been identified, at a scale that allows for strategic and operational planning. In addition to the existing protected areas, we have identified forest areas for future conservation, restoration and adaptive management in a structured, systematic manner across a large region. Our analysis revealed general pattern of structural connectivity of primary forests in intact forest landscapes, however, without distinguishing between different forest types and assuming homogeneous non-forest matrix between those areas. Further studies are needed for understanding the functional ecological aspects of intact forest landscapes and connectivity from the perspective of different groups of organisms in boreal forest landscapes, both forest specialists and generalists, especially taking into account their ecological traits, habitat and landscape requirements and sensitivity to forest clear cutting and other anthropogenic disturbances. Also, further studies on natural (e.g. topography, spatial distribution of open mires and major waterbodies) and human (e.g. historic land-use, transport infrastructure) causes to the patterns of remaining primary forests and intact 
forest landscapes needs further attention (Axelsson and Östlund 2001; Mikusiński et al. 2003; Angelstam et al. 2004; Boucher et al. 2009).

Our study contributes baseline information on the much needed balancing of biogeographical representative protection. Currently, only $8 \%$ of all Swedish forestland and mountain woodland is formally protected (SCB 2019), with a strong bias to the northern boreal and sub alpine mountain areas (Jonsson et al. 2019). We reveal that for the mountain region (here, mountain SRs), the protection levels range from $8.6 \%$ of the total forest land in the south to $36.7 \%$ in the north, from $12.6 \%$ of the pCF in the south to $39.5 \%$ in the north, and that the highest level of pCF-connectivity was found in $22.4 \%$ to $46.7 \%$ of the protected area in the mountain region. The protection levels in the inland and coastal SRs ranges from 1.4 to $4.4 \%$ of the total forest land and from 2.2 to $6.7 \%$ of the pCFarea, which for both area and functionality requirements, i.e. connectivity, is way below the Aichi target \#11 (CBD 2010). Here, forest landscape restoration is needed for successful green infrastructure implementation. Restoring values connected to natural forests takes time, however. For northern boreal Norway spruce forest old-growth habitat characteristics, Lilja et al. (2006) estimated up to a 300 year formation time.

A higher connectivity of primary forests was expected in the mountain area due to the later arrival of modern forestry and due to the emphasis on nature conservation in northwestern Sweden since the 1970s (e.g., Angelstam et al. 2011). From a policy perspective, the effect of the mountain forest border, illustrated in Fig. 3, is noteworthy. This legally defined border delineates the area of a stricter regulation of rotation forestry in Sweden (Jonsson et al. 2019). In the Forestry Act (2018), Section 15 states that the Swedish Forest Agency has to explicitly approve harvesting above this border instead of passively acknowledging applications, and Sect. 18 that harvesting can be prohibited if values associated with nature conservation, cultural heritage or reindeer husbandry may be negatively affected. Obviously, this policy regulation has helped secure the intact forest landscape, and thus represents an example of a policy that in practice successfully supports landscape approaches, which is not commonly recognized (Sayer 2009; Chazdon et al. 2017; Mansourian 2017). However, the narrow west to east extension of the
Scandinavian Mountains Green Belt and also existing connectivity gaps, clearly indicates that further forest fragmentation and loss may cause a "sledgehammer" (Barnosky et al. 2012) effect and, potentially, irreversible loss of the widespread and contagious intact forest values. This is particularly important with respect to the areas with low forest connectivity that has resulted from the extensive landscape transformation in the inland and coastal areas of northern Sweden as well as generally across the boreal forest biome (e.g., Potapov et al. 2017; Peura et al. 2018; Svensson et al. 2018). Hence, maintaining and strengthening a restrictive forestry policy above the mountain forest border, and also promoting a more ambitious conservation policy generally in the boreal biome, is much needed to secure effective and functional conservation, green infrastructure, and future provisioning of ecosystems services and ecosystem adaptive capacity in boreal forest landscapes.

\section{Conclusions}

This study focused on one of very few large intact forest landscapes in northern Europe, where we identified and analyzed distribution, density and connectivity of remnant primary forests, using proxies generated by remote sensing mapping on forest area not subject to systematic rotation forestry.

Our results reveal that close to $60 \%$ of the forest land remains intact, including all narrow, small and unproductive forests that are not subject to forestry, but with the absolute majority in a belt consisting of contiguous, connected and semi-connected forests extending south to north along the Scandinavian mountain range. We detected vast areas of forest components 10,000 ha in size and larger, encompassing half of the total area of intact forests in the study region, and an overall high connectivity within protected forests. Our results also show that currently not protected forests contribute substantially to connectivity, while connectivity gaps exists in the southern parts of the Scandinavian Mountains Green Belt. There, forests are severely fragmented and continuity values are lost, and thus forest landscape restoration is needed to re-establish connectivity and green infrastructure functionality. The Scandinavian mountains green belt should be regarded as an essential asset in national, European and global conservation policies 
as an ecological legacy and critical mainland source for species, biodiversity, ecosystem services, climate change resilience and land use adaptive capacity for a very large region of the boreal biome.

Acknowledgements Open access funding provided by Swedish University of Agricultural Sciences. This study was funded by the Swedish Environmental Protection Agency, grant NV-03501-15. We acknowledge data support from Metria AB, and scientific as well as native language review on an earlier version of the manuscript by Dr. John P. Ball, the Swedish University of Agricultural Sciences.

Open Access This article is licensed under a Creative Commons Attribution 4.0 International License, which permits use, sharing, adaptation, distribution and reproduction in any medium or format, as long as you give appropriate credit to the original author(s) and the source, provide a link to the Creative Commons licence, and indicate if changes were made. The images or other third party material in this article are included in the article's Creative Commons licence, unless indicated otherwise in a credit line to the material. If material is not included in the article's Creative Commons licence and your intended use is not permitted by statutory regulation or exceeds the permitted use, you will need to obtain permission directly from the copyright holder. To view a copy of this licence, visit http://creativecommons.org/licenses/by/4.0/.

\section{References}

Aerts R, Honnay O (2011) Forest restoration, biodiversity and ecosystem functioning. BMC Ecol 11:29

Ahlcrona E, Giljam C, Wennberg, S (2017a) Kartering av kontinuitetsskog i boreal region. Metria $\mathrm{AB}$ på uppdrag av naturvårdsverket, Stockholm, Sweden, p 79 (In Swedish).

Ahlcrona E, Giljam C, Keskitalo C, Klein J, Naumov V (2017b) Precisera kartering av kontinuitetsskog i Västernorrlands län. Metria $\mathrm{AB}$ på uppdrag av naturvårdsverket, Stockholm, Sweden, p 31 (In Swedish).

Angelstam P, Axelsson R, Elbakidze M, Laestadius L, Lazdinis M, Nordberg M, Pătru-Stupariu I, Smith M (2011) Knowledge production and learning for sustainable forest management on the ground: Pan-European landscapes as a time machine. Forestry. https://doi.org/10.1093/forestry/ cpr048

Angelstam P, Manton M, Green M, Jonsson BG, Mikusiński G, Svensson J, Sabatini FM (2020) Sweden does not meet agreed national and international forest biodiversity targets: a call for adaptive landscape planning. Landsc Urban Plan 202:103838

Angelstam P, Mikusiński G, Fridman J (2004) Natural forest remnants and transport infrastructure-does history matter for biodiversity conservation planning? Ecol Bull 51:149-162
Arts B, Buizer M, Horlings L, Ingram V, van Osten C, Opdam P (2017) Landscape approaches: a state-of-the-art review. Annu Rev Environ Resour 42:439-463

Axelsson A-L, Östlund L (2001) Retrospective gap analysis in a Swedish boreal forest landscape using historical data. For Ecol Manag 147:109-122

Barnosky AD, Hadly E, Bascompte J, Berlow EL, Brown JH, Fortelius M, Getz WM, Harte J, Hastings A, Marquet PA, Martinez ND (2012) Approaching a state shift in Earth's biosphere. Nature 486:52-58

Blicharska M, Smithers RJ, Hedblom M, Hedenås H, Mikusiński G, Pedersen E, Sandström P, Svensson J (2017) Shades of grey challenge practical application of the cultural ecosystem services concept. Ecosyst Serv 23:55-70

Blumroeder JS, Burova N, Winter S, Goroncy A, Hobson PR, Shegolev A, Dobrynin D, Amosova I, Ilina O, Parinova T, Volkov A (2019) Ecological effects of clearcutting practices in a boreal forest (Arkhangelsk Region, Russian Federation) both with and without FSC certification. Ecol Ind 106:105461

Boucher Y, Arseneault D, Sirois L, Blais L (2009) Logging pattern and landscape changes over the last century at the boreal and deciduous forest transition in Eastern Canada. Landsc Ecol 24:171-184

Braaker S, Moretti M, Boesch R, Ghazoul J, Obrist MK, Bontadina F (2014) Assessing habitat connectivity for grounddwelling animals in an urban environment. Ecol Appl 24(7):1583-1595

CBD (2010) Convention on biological diversity strategic plan for biodiversity 2011-2020 and the Aichi targets. Convention on Biological Diversity, Montreal. https://www. cbd.int/sp/targets/. Accessed March 2019.

Chazdon RL (2018) Protecting intact forests requires holistic approaches. Nat Ecol Evol 2:915

Chazdon RL, Brancalion PHS, Laestadius L, Bennett-Curry A, Buckingham K, Kumar C, Moll-Rocek J, Vieira IC, Wilson SJ (2016) When is a forest a forest? Forest concepts and definitions in the era of forest and landscape restoration. Ambio 45:538-550

Chazdon RL, Brancalion PHS, Lamb D, Laestadius L, Calmon M, Kumar C (2017) A policy-driven knowledge agenda for global forest and landscape restoration. Conserv Lett 10:125-132

Circuitscape (2018) Circuitscape software Python package v. 4.0.5. https://www.circuitscape.org. Accessed March 2018.

Copernicus (2018) Copernicus Land Monitoring Service website. https://land.copernicus.eu/. Accessed March 2018.

Curtis PG, Slay CM, Harris NL, Tyukavina A, Hansen MC (2018) Classifying drivers of global forest loss. Science 361(6407):1108-1111

Defries RS, Rudel T, Uriarte M, Hansen M (2010) Deforestation driven by urban population growth and agricultural trade in the twenty-first century. Nat Geosci 3:178-181

Dickson BG, Albano CM, Anantharaman R, Beier P, Fargione J, Graves TA, Gray ME, Hall KR, Lawler JJ, Leonard PB, Littlefield CE (2019) Circuit-theory applications to connectivity science and conservation. Conserv Biol 33:239-249

Dickson BG, Roemer GW, McRae BH, Rundall JM (2013) Models of regional habitat quality and connectivity for 
pumas (Puma concolor) in the southwestern United States. PLoS ONE. https://doi.org/10.1371/journal.pone.0081898

Dondina O, Orioli V, D’Occhio P, Luppi M, Bani L (2017) How does forest species specialization affect the application of the island biogeography theory in fragmented landscapes? J Biogeogr 44:1041-1052

EC (2020) EU Biodiversity strategy for 2030-Bringing nature back into our lives. European Commission 380, Brussels

Ecke F, Magnusson M, Hörnfeldt B (2013) Spatiotemporal changes in the landscape structure of forests in northern Sweden. Scandinavian Journal of Forest Management 28:651-667

Elmhagen B, Kindberg J, Hellström P, Angebjörn A (2015) A boreal invasion in response to climate change? Range shifts and community effects in the borderland between forest and tundra. Ambio 44:39-50

Esseen P-A, Ehnström B, Ericson L, Sjöberg K (1997) Boreal forests. Ecol Bull 46:16-47

Esseen P-A, Hedström Ringvall A, Harper KA, Christensen P, Svensson J (2016) Factors driving structure of natural and anthropogenic forest edges from temperate to boreal ecosystems. J Veg Sci. https://doi.org/10.1111/jvs.12387

Forest Europe (2015) State of Europe's Forests 2015. Ministerial Conference on the Protection of Forests in Europe, Madrid. https://www.foresteurope.org/docs/fullsoef2015. pdf. Accessed March 2018.

FRA (2020) General forest resources assessment 2020. Terms and definitions. Forest resources assessment working paper 188. Food and Agriculture Organization of the United Nations, p 26

Grêt-Regamey A, Brunner SH, Kienast F (2012) Mountain ecosystem services: who cares? Mt Res Dev 32(S1):S23S34

Gustafsson L, Ahlén I (1996) Geography of plants and animals. National Atlas of Sweden. SNA Publishing, Stockholm

Gustafsson L, Baker SC, Bauhus J, Beese WJ, Brodie A, Kouki J, Lindenmayer DB, Lõhmus A, Pastur GM, Messier C, Neyland M (2012) Retention forestry to maintain multifunctional forests: a world perspective. Bioscience 62:633-645

Haddad NM, Brudvig LA, Clobert J, Davies KF, Gonzalez A, Holt RD, Lovejoy TE, Sexton JO, Austin MP, Collins CD, Cook WM (2015) Habitat fragmentation and its lasting impact on Earth's ecosystems. Sci Adv. https://doi.org/10. 1126/sciadv. 1500052

Hansen MC, Potapov PV, Moore R, Hancher M, Turubanova SA, Tyukavina A, Thau D, Stehman SV, Goetz SJ, Loveland TR, Kommareddy A (2013) High-resolution global maps of 21 st-century forest cover change. Science 342:850-853

Hedenås H, Christensen P, Svensson J (2016) Changes in vegetation cover and composition in the Swedish mountain region. Ecol Monit Assess 188:452

Heino M, Kummu M, Makkonen M, Mulligan M, Verburg PH, Jalava M, Räsänen TA (2015) Forest loss in protected areas and intact forest landscapes: a global analysis. PLoS ONE. https://doi.org/10.1371/journal.pone.0138918

Heller NE, Zavaleta ES (2009) Biodiversity management in the face of climate change: a review of 22 years of recommendations. Biol Conserv 142:14-32
Hemäläinen A, Strengbom J, Ranius T (2017) Conservation value of low-productivity forests measured as the amount and biodiversity of dead wood and saproxylic beetles. Ecol Appl 28:1011-1019

Hermoso V, Morán-Ordóñez A, Lanzas M, Brotons L (2020) Designing a network of green infrastructure for the EU. Landsc Urban Plan 195:103732

IPBES (2018) Summary for policymakers of the assessment report on land degradation and restoration of the Intergovernmental Science-Policy Platform on Biodiversity and Ecosystem Services. IPBES secretariat, Bonn

Jansson R, Nilsson C, Keskitalo EHC, Vlasova T, Sutinen ML, Moen J, Chapin III FS, Bråthen KA, Cabeza M, Callaghan TV, van Oort B (2015) Future changes in the supply of goods and services from natural ecosystems: prospects for the European north. Ecol Soc 20:32

Jones KR, Venter O, Fuller RA, Allan JR, Maxwell SL, Negret PJ, Watson JEM (2018) One-third of global protected land is under intense human pressure. Science 360:788-791

Jonsson BG, Svensson J, Mikusiński G, Manton M, Angelstam P (2019) European Union's last intact forest landscape is at a value chain crossroad between multiple use and intensified wood production. Forests 10:564

Koen EL, Bowman J, Sadowski C, Walpole AA (2014) Landscape connectivity for wildlife: development and validation of multispecies linkage maps. Methods Ecol Evol 5:626-633

Kuuluvainen T (2009) Forest management and biodiversity conservation based on natural ecosystem dynamics in Northern Europe: the complexity challenge. Ambio 38:309-315

Kuuluvainen T, Hofgaard A, Aakala T, Jonsson BG (2017) North Fennoscandian mountain forests: history, composition, disturbance dynamics and the unpredictable future. For Ecol Manag 385:140-149

Lilja S, Wallentinus T, Kuuluvainen T (2006) Structure and development of old Picea Abies forest in northern boreal Fennoscandia. Écoscience 13:181-192

Liquete C, Kleeschulte S, Dige G, Maes J, Grizetti B, Olah B, Zulian G (2015) Mapping green infrastructure based on ecosystem services and ecological networks: a Pan-European case study. Environ Sci Policy 54:268-280

Lundmark A, Josefsson T, Östlund L (2013) The history of clear-cutting in northern Sweden-driving forces and myths in boreal silviculture. For Ecol Manag 307:112-122

Mahr MH (2007) Transboundary conservation and the Yellowstone to Yukon Conservation Initiative. In: Prato A, Fagre D (eds) Sustaining rocky mountain landscapes: science, policy and management for the crown of the continent ecosystem. Resources for the Future Press, Washington, pp 229-248

Mansourian S (2017) Governance and forest landscape restoration: a framework to support decision-making. J Nat Conserv 37:21-30

Mantyka-Pringle CS, Martin TG, Rhodes JR (2012) Interactions between climate and habitat loss effects on biodiversity: a systematic review and meta-analysis. Glob Change Biol 18:1239-1252

McGuire JL, Lawler JJ, McRae BH, Nuñez TA, Theobald DM (2016) Achieving climate connectivity in a fragmented landscape. Proc Natl Acad Sci USA 113(26):7195-7200 
McRae BH, Dickson BG, Keitt TH, Shah VB (2008) Using circuit theory to model connectivity in ecology, evolution, and conservation. Ecology 89:2712-2724

Mikusiński G, Angelstam P, Sporrong U (2003) Distribution of deciduous stands in villages located in coniferous forest landscapes in Sweden. Ambio 32:520-526

Moen J, Rist L, Bishop K, Chapin III FS, Ellison D, Kuuluvainen T, Petersson H, Puettmann KJ, Rayner J, Warkentin IG, Bradshaw CJ (2014) Eye on the taiga: removing global policy impediments to safeguard the boreal forest. Conserv Lett 7:408-418

Müller J, Noss RF, Thorn S, Bässler C, Leverkus AB, Lindenmayer D (2018) Increasing disturbance demands new policies to conserve intact forest. Conserv Lett. https://doi. org/10.1111/conl.1244

Neteler M, Bowman M, Landa M, Metz M (2012) GRASS GIS: a multi-purpose open source GIS. Environ Model Softw 31:124-130

Nordström E (2017) Naturvårdshänsyn på hyggen 1960- till 2010-tal—vad har hänt på 50 år? Thesis \# 282. Swedish University of Agricultural Sciences, Southern Swedish Forest Research Centre, Alnarp, p 40

Oliphant TE (2007) Python for scientific computing. Comput Sci Eng 9:10-20

Östlund L, Hörnberg G, DeLuca TH, Liedgren L, Wikström P, Zackrisson O, Josefsson T (2015) Intensive land use in the Swedish mountains between AD 800 and 1200 led to deforestation and ecosystem transformation with longlasting effects. Ambio 44:508-520

Pape R, Löffler J (2012) Climate change, land use conflicts, predation and ecological degradation as challenges for reindeer husbandry in northern Europe: what do we really know after half a century of research? Ambio 41:421-434

Peura M, Burgas D, Eyvindson K, Repo A, Mönkkönen M (2018) Continuous cover forestry is a cost-efficient tool to increase multifunctionality of boreal production forests in Fennoscandia. Biol Conserv 217:104-112

Pfeifer M, Lefebvre V, Peres CA, Banks-Leite C, Wearn OR, Marsh CJ, Butchart SH, Arroyo-Rodríguez V, Barlow J, Cerezo A, Cisneros L (2017) Creation of forest edges has a global impact on forest vertebrates. Nature 551:187-191

Potapov P, Hansen MC, Laestadius L, Turubanova S, Yaroshenko A, Thies C, Smith W, Zhuravleva I, Komarova A, Minnemeyer S, Esipova E (2017) The last frontiers of wilderness: tracking loss of intact forest landscapes from 2000 to 2013. Sci Adv 3:1-13

Potapov P, Turubanova S, Hansen MC (2011) Regional-scale boreal forest cover and change mapping using Landsat data composites for European Russia. Remote Sens Environ 115:548-561

Potapov P, Yaroshenko A, Turubanova S, Dubinin M, Laestadius L, Thies C, Aksenov D, Egorov A, Yesipova Y, Glushkov I, Karpachevskiy M (2008) Mapping the world's intact forest landscapes by remote sensing. Ecol Soc 13:51

Pulsford I, Worboys GL, Howling G (2010) Australian Alps to Atherton connectivity conservation corridor. In: Worboys GL, Francis WL, Lockwood M (eds) Connectivity conservation management. A global guide. Earthscan, London, pp 96-105
QGIS Development Team (2017) QGIS Geographic Information System. Open Source Geospatial Foundation. https:// qgis.org. Accessed March 2017.

Riitters K, Wickham J, Costanza JK, Vogt P (2016) A global evaluation of forest interior area dynamics using tree cover data from 2000 to 2012. Landsc Ecol 31:137-148

Sabatini FM, Burrascano S, Keeton WS, Levers C, Lindner M, Pötzschner F, Verkerk PJ, Bauhus J, Buchwald E, Chaskovsky O, Debaive N (2018) Where are Europe's last primary forests? Divers Distrib 24:1426-1439

Sandström P, Cory J, Svensson J, Hedenås H, Jougda L, Borchert N (2016) On the decline of ground lichen forests in the Swedish boreal landscape: implications for reindeer husbandry and sustainable forest management. Ambio 45:415-429

Sayer J (2009) Reconciling conservation and development: are landscapes the answer? Biotropica 41:649-642

SCB Protected Nature 2018 (2019) Sweden's Official Statistics; Report MI 41 SM 1901; SCB: Stockholm, Sweden (Report in Swedish). https://www.scb.se/contentassets/ 0581e8801be54a20983ef7afd0281214/mi0603_2018a01_ sm_mi41sm1901.pdf. Accessed 28 June 2019

Slätmo E, Nilsson K, Turunen E (2019) Implementing green infrastructure in spatial planning in Europe. Landscape $8: 62$

SLU (2018) Forest statistics 2018, Official statistics of Sweden. Swedish University of Agricultural Sciences, Umeå (In Swedish)

Spathelf P, Stanturf J, Kleine M, Jandl R, Chiatante D, Bolte A (2018) Adaptive measures: integrating adaptive forest management and forest landscape restoration. Ann For Sci 75:55. https://doi.org/10.1007/s13595-018-0736-4

Stanturf JA, Palik BJ, Dumroese RK (2014) Contemporary forest restoration: a review emphasizing function. For Ecol Manag 331:292-323

Svensson J, Andersson J, Sandström P, Mikusiński G, Jonsson BG (2018) Landscape trajectory of natural boreal forest loss as an impediment to green infrastructure. Conserv Biol 33:152-163

Sverdrup-Thygeson A, Sörgard G, Rusch GM, Barton DN (2014) Spatial overlap between environmental policy instruments and areas of high conservation value in forest. PLoS ONE 11:1-18

Swedish Environmental Protection Agency (2018) Miljödataportalen. https://mdp.vic-metria.nu/miljodataportalen/. Accessed March 2018

Swedish Forestry Act (2018) Skogsvårdslag, Svensk Författningssamling (SFS) 1979:429. Revised 1993:553 and updated to 2018. (in Swedish)

Swedish Forest Agency (2018) Skogsdataportalen, gräns för fjällnära skog (the mountain foothills border). https:// skogsdataportalen.skogsstyrelsen.se/Skogsdataportalen/. Accessed March 2018.

Terry A, Ullrich K, Riecken U (2006) The green belt of Europe. From vision to reality. IUCN, Gland

Thom D, Golivets M, Edling L, Meigs GW, Gourevitch JD, Sonter LJ, Galford GL, Keeton WS (2019) The climate sensitivity of carbon, timber, and species richness covaries with forest age in boreal-temperate North America. Glob Change Biol 25:2446-2458 
Tucker MA, Böhning-Gaese K, Fagan WF, Fryxell JM, Van Moorter B, Alberts SC, Ali AH, Allen AM, Attias N, Avgar T, Bartlam-Brooks H (2018) Moving in the Anthropocene: global reductions in terrestrial mammalian movement. Science 359:466-469

UN (2019) United Nations decade on ecosystem restoration (2021-2030). Resolution adopted by the General Assembly on 1 March 2019, Seventy-third session, Agenda item 14. A/RES/73/284.

Venter O, Sanderson EW, Magrach A, Allan JR, Beher J, Jones KR, Possingham HP, Laurance WF, Wood P, Fekete BM, Levy MA (2016) Sixteen years of change in the global terrestrial human footprint and implications for biodiversity conservation. Nat Commun 7:12558

Wallenius T, Niskanen L, Virtanen T, Hottola C, Brumelis G, Angervuori A, Julkunen J, Pihlström M (2010) Loss of habitats, naturalness and species diversity in Eurasian forest landscapes. Ecol Indic 10(2010):1093-1101

Watson JEM, Evans T, Venter O, Williams B, Tulloch A, Stewart C, Thompson I, Ray JC, Murray K, Salazar A, McAlpine C (2018) The exceptional value of intact forest ecosystems. Nat Ecol Evol 2:599-610

Zeller KA, McGarigal K, Whiteley AR (2012) Estimating landscape resistance to movement: a review. Landsc Ecol 27(6):777-797

Publisher's Note Springer Nature remains neutral with regard to jurisdictional claims in published maps and institutional affiliations. 